M E L V I N L A N D B E R G

University of Kansas

\title{
John R. Dos Passos: His Influence on the Novelist's Early Political Development
}

JOHN R. DOS PASSOS SR. (1844-1917), THE FATHER OF THE NOVELIST, DESERVES to be remembered in his own right. I shall in this study discuss his career as a social critic, lawyer and author, and try to give some sense of its unusual tone. I shall be concerned, not with evaluating the father's career, however, but with suggesting the influence of Dos Passos Sr.'s thought on the novelist's early political development. That some of the novelist's first experiences with political doctrines consisted of simply listening to his father talk ${ }^{1}$ is as important a fact as it is an unextraordinary one. I shall devote my attention to the early, and particularly the radical, phase of the novelist's development because it culminated, during the late 1920s and the 1930s, in the writing of the trilogy U.S.A., his major literary achievement. Aspects of the senior Dos Passos' influence on the son's later, conservative thought will probably suggest themselves. ${ }^{2}$ The novelist being very much a living contemporary, I will not attempt to explore his private emotional life.

John R. Dos Passos Sr. was the son of a poor immigrant from Madeira and of an American woman of Quaker family. ${ }^{3}$ Dos Passos Sr. came to New York in 1867, after a term as office boy in Philadelphia, service in the Pennsylvania state militia, and a period spent attending law lectures at the University of Pennsylvania.4 "The same dream of big things

1 John Dos Passos, U.S.A.: The 42nd Parallel (New York: Modern Library [1939]), pp. 13-14, 57-58, 173-74.

2 Dos Passos wrote to the author: "I was delighted with your treatment of my father. It's only in recent years that $I$ have appreciated how deep his influence was on the cast of my mind." Letter, March 6, 1958.

3 Communication from Dos Passos, quoted in Georges-Albert Astre, Themes et structures dans l'oeuvre de John Dos Passos, I (Paris, 1956), p. 29.

4 New York Times, January 28, 1917, Sec. 7, p. 3. Compare The 42nd Parallel, p. 166. New York Times, January 28, 1917, Sec. 7, p. 3. Dos Passos noted after the present article was in print: "a term as office boy and apprenticeship in a Philadelphia law office." Referring to his grandmother, he substituted: "and of Lucy Catell, said to be of Quaker origin." Letter, April 20, 1964. 
that leads so many ambitious young men all over the United States to come to New York led his footsteps hither," a colleague said of him in a eulogy a few days after his death. "Many of these young men are disappointed, but he was not-he made good." The comment becomes almost ironic when one remembers how the son was to play on the theme of making good in New York in his Manhattan Transfer (1925). The father not only made good, but he displayed unusual versatility and originality in the way in which he did it. First he became a well-known criminal lawyer. Perhaps his greatest triumph in this phase of his career was his getting the murder verdict against Edward S. Stokes set aside after Stokes had been found guilty of killing the Civil War financier "Jim" Fisk in a quarrel over a mistress. ${ }^{5}$ Afterwards Dos Passos Sr. opened an office in the Mills Building, opposite the New York Stock Exchange. ${ }^{6}$ Soon he was enjoying a lucrative practice among the brokers and operators. When he found that there was no good book available on his specialty, the law of commercial exchange, he wrote what became the standard work on the subject.

There is real irony in the fact that the elder John Dos Passos did much to make possible the consolidation of American business, which was to further the growth of industry (one of his son's earliest bettes noires) and strengthen the influence of corporations upon government. Many Wall Sereet firms employed him as a confidential advisor, for he was not only a master of corporation law but also of reconciling conflicting business inverests. After the original "Sugar Trust," formed in 1887, was declared illegal by the New York Court of Appeals, H. O. Havemeyer called upon him to onganize the new American Sugar Refining Company. Dos Passos Sr. did more than merely draw up papers; he actually planned the formation of the corporation. ${ }^{8}$ For this he received the largest fee on record for such work up to that time.? According to his obituary in the New York Times, he was credited with much of the advice according to which the trust was for many years kept out of the reach of the law. ${ }^{10}$ In addition to helping create the sugar trust, the elder Dos Passos helped to form the American Thread Company and Cramp's Ship Works, and to reorganize the Texas and Pacific, the Reading and the Erie Railroads. ${ }^{11}$

5 Henry Wollman, "John Dos Passos," Case and Comment, XXIV (July 1917), 163-65. - New York Times, January 28, 1917, Sec. 7, p. 3.

7 John R. Dos Passos Sr, 4 Treatise on the Law of Stock-Brokers and Stock-Exchanges (New York, 1882).

8 Wollman, Case and Comment, XXIV, 163-65.

O H. W. Howard Knott, "John Randolph Dos Passos," Dictionary of American Biography, V, 388-89.

10 New York Times, January 28, 1917, Sec. 7, p. 3.

11 Wollman, Case and Comment, XXIV, 168-65. 
A mere outline of his career does not dispose of him, however. John $\mathbf{R}$. Dos Passos Sr. was an intellectually aggressive man who aspired to be more than a creature of the new age. He was unusually well read, possessing considerable knowledge of classical and modern history and literature, as well as of jurisprudence. He enjoyed being able to refer his actions and opinions to ultimate principles and despised the new crop of lawyers who were nurtured on casebooks rather than on Blackstone. His economic thought, as revealed in his books and pamphlets, shows real development. Dos Passos Sr. always remained fundamentally conservative, but toward the end of his career his conservatism had become the adaptable type that is apt to be almost as unpopular as radicalism in conservative circles.

Dos Passos Sr. was a friend of William McKinley and stumped Pennsylvania and Virginia for him in $1896 .{ }^{12}$ The opinions that he held at the turn of the century show him enthusiastic about the prospect of an American empire; however, they reveal him as a proponent of personal liberty as well as of imperialism.

During or shortly before 1896, the year of Dos Passos Jr.'s birth, there appeared a pamphlet Argument of John R. Dos Passos, Esq. of New York in Favor of Recognition of Cuba by the United States. In it Dos Passos Sr. wrote that this country was justified in encouraging the Cuban revolutionists because Cuba was nearby; because politically and morally she ought to be a republic; and because the United States' commercial interests there were so great that the best writers on international law, citing the doctrine of self-preservation, sanctioned the nation's intervening to protect the property and rights and to advance the interests and commerce of its citizens. He granted that these arguments alone might not always warrant intervention. ${ }^{13}$ One other factor did, however. The King of Spain had proclaimed Cuba under perpetual martial law. Any state which deprives its citizens of the three absolute rights of an individual-the right of personal security, of personal liberty and of private propertyis a despotism. Its people are justified in rebelling to rescue themselves. Any outside civilized nation has a duty to acknowledge their belligerency and to succor and support them. ${ }^{14}$

The philosophy of the pamphlet on Cuba was much more liberal than that of a pamphlet which Dos Passos Sr. published in 1900 defending McKinley's policies in the Philippines. In this work, which took issue with the criticisms of Carl Schurz and the anti-imperialists, Dos Passos Sr. displayed a crude legalistic hardness. He did not confine himself to dis-

12 Ibid.

13 John R. Dos Passos Sr., Argument of John R. Dos Passos, Esq. of New York in Favor of Recognition of Cuba by the United States (n.d.), p. 10.

14 Ibid., Pp. 13-16. 
crediting Aguinaldo as a Philippine patriot or to pointing out that the United States had no reason to believe that he represented the Philippine people. ${ }^{15} \mathrm{He}$ insisted that the United States had not promised or acknowledged Philippine independence and was not bound to do so under international law. When a cession of territory takes place, the inhabitants need not be consulted, he wrote. It was possible to be so tender and delicate about the rights of people as to be impracticable, visionary and "platonic." 16 Science had annihilated space and time, and commerce which might not have interested the country fifty years ago might now be a necessity. Manila Bay was not as many days away as Oregon had once been, and Oregon had been annexed. ${ }^{17}$ Since the Philippines had never governed themselves or asked for independence from Spanish domination, it was legitimate to ask them to go through a period of probation, Dos Passos Sr. argued; if they should ever ask for independence with nearunanimity, as he for some reason assumed that the people of the thirteen colonies had done, then the question would be a real one.18

Also belonging to the period of the elder Dos Passos' exuberance over empire was The Anglo-Saxon Century (1903), a book far removed both from his professional interests and from the political issues of the moment. It was a plea for a union between the people of the United States and of Great Britain (including the inhabitants of their colonies)-for common citizenship, freedom of commercial intercourse between the two nations, and uniform currency and standards of weights and measures. Canada was to divide itself into states and become part of the United States, and an arbitration tribunal was to be set up to decide all questions that arose under the treaty between Great Britain and the newly-enlarged United States. ${ }^{10}$

Behind the plan was Dos Passos' desire to justify the American empire in the same way as the British did theirs as well as to link the destiny of the new empire with that of the older one. The American Revolution was actually, he wrote, an expansion and propagation of the Anglo-Saxon race and its principles of liberty, law and government.20 The growth of Anglo-American power and influence was not determined by conscious will but by underlying forces shaping the progress of the human race.21 To the Anglo-Saxon peoples these forces had entrusted the civilization and Christianization of the world.22 Since fate had made the United States a world power, the nation ought to be ready to support the growing busi-

15 John R. Dos Passos Sr., A Defence of the McKinley Administration from Attacks of Mr. Carl Schurz and Other Anti-Imperialists (1900), passim.

16 Ibid., p. $74 . \quad 17$ Ibid., p. $77 . \quad 18$ Ibid., p. 86.

19 John R. Dos Passos Sr., The Anglo-Saxon Century (New York, 1903), pp. 159-208.

20 Ibid., p. $84 . \quad 21$ Ibid., p. $47 . \quad 22$ Ibid., p. 3. 
ness interests of its citizens. ${ }^{23}$ It ought to remember the abstract rules of right and not embark on wars for mere aggrandizement; however, for its own sake and for humanity's sake, once it acquired a colony it ought never to let it go. ${ }^{24}$

The elder Dos Passos was a gold Democrat, not a Republican; he had probably been a Grover Cleveland Democrat before the election of 1896.25 His career as a campaigner for Republican candidates seems to have ended with the death of McKinley. The break with the party was sharp. In 1904 he published a fulminating campaign pamphlet 79 pages long called The Trend of the Republican Party and bearing the legend: "Thou art weighed in the balances of the Constitution and found wanting." The immediate stimulus seems to have been a strong antipathy toward Theodore Roosevelt. Beyond the fact that it had once been for the abolition of slavery, Dos Passos Sr. saw little good in the party. It was living on past achievements. McKinley had sought to revive it, but his death had extinguished all hope. ${ }^{26}$ His successor, Theodore Roosevelt, had not only violated international law by arranging a revolution in Colombia, but he had also, in the Spooner Act which he had negotiated with Nicaragua, violated the command of Congress. ${ }^{27}$

The Republican Party had begun to "do things" to the Constitution long before Mr. Roosevelt's accession, the elder Dos Passos charged. Roosevelt was not "the author of all their strenuosity." 28 First, the party had kept the Southern states out of the Union, although the entire purpose of the war had been to keep them in; the Republicans had, moreover, placed the South in the power of carpetbaggers and adventurers. Second, the party had attacked the executive branch of the government by unjustly trying to impeach Andrew Johnson. Third, it had packed the Supreme Court in order to reverse its decision declaring unconstitutional the law creating greenbacks legal tender; this packing had created a precedent that might be used by unscrupulous factions to defeat the Constitution. Fourth, the party had dishonestly placed Hayes in the Presidency, though Tilden had been elected. ${ }^{29}$ Finally, it had undermined representative federal government by "muzzling free speech" in Congress through a Committee on Rules and by placing Congress under the domination of an oligarchy of 24 members. ${ }^{30}$

The Republican orators claimed responsibility for the material wealth of the nation. The elder Dos Passos doubted the justice or even the pertinence of this claim. It was true that the incentive to wealth was honorable

23 Ibid., p. 4.

25 Letter to author from Dos Passos, June 26, 1956.

26 John R. Dos Passos Sr., The Trend of the Republican Party (New York, 1904), p. 3. 27 Ibid., p. 66. 28 Ibid., p. 45.

29 Ibid., pp. 65-66. 30 Ibid., p. 70. 
and useful, he added, and that the nation ought to encourage it. But money had become a substitute for character. It was being used to buy social and political position. Of what use was the new material prosperity, he asked, if the nation was not more elevated and refined than before? ${ }^{31}$

The elder Dos Passos once stated in his son's hearing that with his ideas he could not be elected a notary public or a dog-catcher in any county of the state, not if he had all the money in the world. ${ }^{32}$ The idea of a common Anglo-American citizenship would certainly have been used against him with telling effect if he had sought public office. At least two other of his ideas would have harmed him. First, there was his desire to deny citizenship - or at least the vote— to the foreign-born in the United States. In The Anglo-Saxon Century, Dos Passos Sr. had maintained that admixture of blood makes a nation strong and is necessary for the diffusion of civilization. In the United States, he had added, foreigners assimilated themselves almost immediately to the laws, manners and conditions of the country; they became the most fervent advocates of democracy. ${ }^{38}$ Four years later, in an address that he delivered to the Virginia State Bar Association, he reversed the opinion. There were two defects hampering government in the United States, he told the audience. One was the inordinate increase in the number of representatives in the lower houses of the United States Congress and of state assemblies. The other was the indiscriminate admission of foreigners to citizenship and suffrage. ${ }^{34}$ Liberal naturalization laws, inevitable in the early days of the republic, had now become a menace. They had destroyed the prestige and honor that had once been attached to American citizenship and had dampened the patriotism of native-born citizens. So long as interchangeable citizenship between countries where English law and the English language prevailed remained an unrealized dream, he wished to strengthen the United States so that it could advance its destiny alone. To make America a union of citizens who understood and valued the rights of life, liberty and property, he called for the denial of suffrage to the "rabble and refuse of foreign countries." Only "descendants of American parents" should be allowed to vote. If the country had to encourage immigration, it should grant newcomers citizenship without suffrage. ${ }^{85}$

Most of the evils in the country arose, Dos Passos Sr. felt, from the ignorance or apathy of the voters. There being no way of curtailing the

31 lbid., pp. 76-78.

32 Dos Passos, The 42nd Parallel, p. 174.

83 Dos Passos Sr., Anglo-Saxon Century, pp. 103-5.

84 John R. Dos Passos Sr., The Results and Responsibilities of Our Representative Democracy (n.d.), p. 7.

85 Ibid., pp. 12-14. 
suffrage, he stated subsequently in an argument against proposals for direct primaries, the true friend of the people was the one who provided means of protecting them against their own imperfections:" "Vox populi, vox dei" did not apply when the people were drunk with passion; then vox populi was the voice of the devil. ${ }^{37}$ The indirect nomination of officials was in sympathy with the form and theory of the United States government, while the increasing number and complexity of public questions made the professional politician necessary. ${ }^{38}$ If the people chose, nominated and elected their officers, there would be mob elections. ${ }^{39}$ The direct primary reminded the elder Dos Passos of the secret ballot, a disastrous experiment which, he charged, had converted the free American citizen into a sneak; its abolition would be a real reform. .0 $^{40}$

He expressed his suspicion of democracy again two years later in a pamphlet arguing against a proposition to have United States senators elected directly by the people. The pamphlet as a whole dealt with the rights of property, the nature of the original Union and the fact that the Senate was an advisory and a judicial as well as a legislative body. ${ }^{41}$ The United States Senate, like the British House of Lords, Dos Passos declared, protected property against attacks by excited masses. All classes of the people being property owners, property interests were entitled to as much protection as the personal rights of the proletariat. (The word proletariat, which was coming into use, he added interestingly, was in this country as yet happily limited to the individual who could pack his belongings in a satchel and segregate himself from society.) ${ }^{42}$ Unless the identity of the Senate were maintained, he warned, America might be faced with a situation reminiscent of the French Revolution.48

Law reform was one of the elder Dos Passos' continuing interests. During the final years of his life he worked for it more actively than ever before. He went so far as to get William Jennings Bryan, against whom he had campaigned in 1896, to insert in the platform of the Democratic Party a plank pledging such reform. Dos Passos Sr. tried to effect changes in criminal law procedure. The idea that a defendant in a criminal trial ought not to be compelled to testify against himself he traced back to the ecclesiastical insistence on forgiving sins. The doctrine ought never, he declared, to have been transferred to the criminal system. ${ }^{44}$ He insisted

36 John R. Dos Passos Sr., Observations of John R. Dos Passos upon the Question of Direct Primary (1909), p. 4.

87 Ibid., pp. 6-7. $\quad 38$ Ibid., pp. 2-4. $\quad 39$ Ibid., p. $9 . \quad 40$ Ibid., pp. 13-15.

41 John R. Dos Passos Sr., Some Observations on the Proposition to Elect United States Senators by the People (1911), passim.

42 Ibid., pp. 14-16.

43 Ibid., p. 27.

44 John R. Dos Passos Sr., special article on desirable reforms in administration of New York State criminal law, New York Times, March 1, 1914, Sec. 5, p. 4. 
that equality before the law did not exist. Two thousand dollars bail was a bagatelle for a millionaire but might be impossible for a poor man to raise. Court-appointed lawyers did not work as long or as well as the expensive lawyers whom rich men hired. After his conviction, a wealthy man could get a "stay," but a poor man went to jail. Part of the solution which he advocated was a less reverent attitude toward mere legal technicalities and the establishment of an office of Public Defender to protect the rights of the accused. ${ }^{45}$

To Dos Passos Sr. law reform included reforming the lawyer, or purifying and ennobling the profession, ${ }^{46}$ as he put it. In one of his most memorable books, The American Lawyer, he noted that until the Civil War, lawyers had been the social and intellectual aristocrats of the country. ${ }^{47}$ At about that time, law had begun to change from a profession to a business. ${ }^{48}$ Wealth had stolen the lawyer's social position. Many of his duties, such as title searching and collecting bills, had been taken from him by business organizations composed of laymen. Now the lawyer was merely a good businessman. He cared nothing for jurisprudence. Too often he cultivated "every kind of equivocal quality" as a means to success.99 As for patriotism, many lawyers would mangle the Federal or a state constitution beyond recognition to win a case. ${ }^{50}$

The modern lawyer, Dos Passos Sr. charged, was dishonest. He did not concern himself with how his conduct affected the administration of justice or the welfare of the state. He knowingly put forth false pleas and defenses; while claiming to be the representative of his client in court, he was actually the principal actor. ${ }^{51}$

Dos Passos Sr. closed The American Lawyer with a list of underlying difficulties and with some suggested remedies. The remedies included better prelaw and law school education and a longer apprenticeship; the abolition of case law as the fundamental method of legal instruction; an increased emphasis on jurisprudence; a reduction in the number of lawyers in order to improve their morale; and a distinctive gown or badge for lawyers to wear in court to increase respect for the profession. ${ }^{52}$

Dos Passos Sr. wrote two books in which he dealt with a subject that has never ceased to occupy his son's attention, the concentration of corporate wealth in the United States. It was probably the most vexing economic problem of the day. Dos Passos Sr.'s first book on the subject, Com-

45 Ibid.; New York Times, February 8, 1914, Sec. 2, p. 4; letter to the editor, New York Times, February 7, 1915, Sec. 8, p. 1.

46 Letter to the editor, New York Times, January 4, 1914, Sec. 2, p. 14.

47 John R. Dos Passos Sr., The American Lawyer: As He Was-as He Is-as He Can Be (New York, 1919), p. 23. The book first appeared in 1907.

48 Ibid., p. 25.

51 Ibid., p. 130.

49 Ibid., pp. 32-33.

52 Ibid., pp. 164-85.

50 Ibid., p. 25. 
mercial Trusts, was a revision of an argument that he delivered before the Industrial Commission in Washington, D. C., in 1899.53 The second book, Commercial Mortmain, was published seventeen years after his appearance before the Commission. They are significant books because they describe the development of his outlook on the growth of huge corporations.

In Commercial Trusts, Dos Passos Sr. stressed the fact that modern commerce could not thrive without aggregated capital..$^{54}$ As trusts were simply one form of such capital, there was no sense in attacking them alone, he wrote; a realistic attack would have to include partnerships and corporations and would imperil a system under which the country had developed and become prosperous. ${ }^{55}$ (What was more, if it was wrong to combine capital, it was wrong to combine labor.) ${ }^{56}$ Restrictions such as the Sherman Anti-Trust Acts remained unexecuted because the natural laws of trade defy human legislation. ${ }^{57}$ These same natural laws could be relied on to prevent or demolish most commercial monopolies, particularly if they attempted to raise prices to an unusual level. ${ }^{58}$ Legislators ought to remember that when they attacked any of the great industrial combinations, they were harming not the leaders, who could take care of themselves, but hosts of innocent stockholders. ${ }^{59}$

If aggregated capital forced some individuals to suffer, he added, such misfortune during the course of economic development had been the rule from the beginning of the world; the question was one of discovering the greatest good for the greatest number. ${ }^{80}$ If corporations corrupted legislators or judges, there were already penal laws to cover the situation. Besides, it was an unfortunate fact that legislatures often forced businesses to use illegitimate methods to obtain privileges that were entirely proper and necessary. ${ }^{61}$

Though Dos Passos Sr.'s argument in 1901 was against either the Federal or the state governments' imposing further restrictions on the growth of aggregated capital, 62 it conceded that the problem was new and that answers were not yet available; a few more years of experience with the huge combinations would show whether they were good or bad for the country. ${ }^{63}$ Perhaps his professional commitments at the time led him, consciously or unconsciously, to minimize the dangers of aggregated capital. By 1916 he had altered many of his opinions. The desire to concentrate had become a craze, he wrote. In a few years every business would

58 John R. Dos Passos Sr., Commercial Trusts (New York, 1901), p. 1.

ot Ibid., p. 33.

67 Ibid., pp. 68-69, 71-72.

60 Ibid., p. 94.

55 Ibid., pp. 88-89.

58 Ibid., pp. 63-65.

61 Ibid., pp. 99-101.

56 Ibid., p. 86.

59 Ibid., p. 66.

63 Ibid., p. viii.

62 Ibid., pp. 118-26. 
be merged into a corporation. Great aggregations of capital would run all industrial enterprises and would allow people with brains and talent to be no more than their clerks and liveried servants. The commercial and industrial oligarchies would profoundly change the form of the government. They might seek control of newspapers. Their leaders might one day be able to dictate the financial policy of the United States. ${ }^{64}$

Already, he noted, some individuals had become so rich that they could force any industry into one corporation and arbitrarily assign to themselves enormous compensation as promotion expenses. ${ }^{65}$ Was it not possible that the magnates would eventually gain control of all three branches of the Federal government, if not by outright bribery, then by indirect methods? ? $^{68}$ One could no longer rely on restraint based on moral sense, properly the most important bulwark of the republic. Money had no conscience. ${ }^{67}$

The belief that the fundamental aim of an individual or a nation was to make money had, he added, become widespread. It had led to an aristocracy of wealth, claiming social superiority only because it possessed money. This class threatened to become a fourth branch of the government, one that would gradually wipe out the checks and balances of the republican system. ${ }^{88}$

Dos Passos Sr. insisted, as he had in Commercial Trusts, that the answer did not lie with antitrust acts. The country could not treat the normal processes of business as a crime.69 It should look to certain "natural remedies" to aid it in controlling trust and other forms of aggregated capital. These remedies included new inventions; the concentration of labor (which, nevertheless, he again insisted was as obnoxious as that of capital); extravagance; and mismanagement. The country should deny tariff protection to articles controlled by trusts. Finally, it should give the Federal government full power regarding questions of aggregated capital and wealth, rather than seek to deal with them through forty-eight different states. The power, which should be wielded through a reapplied common law punishing acts against public trade, should not be applicable indis-

64 John R. Dos Passos Sr., Commercial Mortmain (New York, 1916), pp. 52-64. 65 Ibid., p. 57.

66 A former law partner of Dos Passos Sr. wrote: "I have not read Commercial Mortmain in many years, but should say that my late uncle and partner in writing it was expressing himself in general terms, and not in opposition to any particular group
of financiers.

"You see, my uncle was both an advocate and an author. In the former capacity he was intent on advancing the interests of his clients, while in the latter he was expressing his own views as based upon historical precedents." Letter to author from Cyril F. dos Passos, June 16, 1957.

67 Dos Passos Sr., Commercial Mortmain, p. 63.

68 Ibid., pp. 65-67.

69 Ibid., p. viii. 
criminately to all aggregations of capital, but only to those which were real evils. ${ }^{70}$

The nearest approach to a remedy for the problem of unlimited individual wealth and of trusts, he held, was through taxation, much of which could be imposed under the new income tax amendment. The government might license monopolies for a fee, or it might heavily tax corporations that had attained monopolistic powers, the taxes being a charge for the privilege of enjoying the powers. The government could fix prices of the products of monopolies at reasonable levels and receive thereby almost enough money to operate without further taxation. Under all circumstances, the government would always retain the power of dissolving monopolies.

A good criterion for declaring a "monopoly," Dos Passos Sr. wrote, was the earning power of a person or a business. A point had now been reached where huge corporate and individual incomes had to be taxed by the government and individual fortunes limited. (Some of the fortunes were so large that it would require a most phenomenal extravagance to dissipate them. ${ }^{71}$ ) Twenty-five million dollars might be set as a limit for personal fortunes and all annual income in excess of 4 per cent of that amount (one million dollars) be subjected to taxation. A chartered steel monopoly earning one hundred and fifty million dollars in profits might pay one third in taxes. ${ }^{72}$

The elder Dos Passos lived through his son's Harvard days and remained a public figure during that entire period. The effect upon Dos Passos of his father or the memory of him has been complex. It is easy to speak of the son as, early in life, rebelling against his father's ideas and attitudes. The elder Dos Passos' sympathies were usually with the top-dog. Although Dos Passos Sr. was the son of a Portuguese immigrant, he identified himself with a triumphant Anglo-Saxon race. He would have denied suffrage to immigrants. He advocated imperialism on the ground that it would benefit American business. In so far as he called for reform, he seems to have done so, not from an urge to help particular human beings, but from a desire to perfect institutions. The son, on the other hand, found himself in sympathy with Mediterranean anarchists, exploited immigrant laborers and Mexican peons. ${ }^{78}$

70 Ibid., pp. 79-100.

71 Ibid., p. 81.

72 Ibid., pp. 79-100.

78 See, for instance, John Dos Passos, Rosinante to the Road Again (New York, 1922), passim.; Facing the Chair (Boston, 1927), pp. 57-58; "Zapata's Ghost Walks," New Masses, III (September 1927), 11-12. 
Nevertheless, the extent to which the novelist shared interests, ideas and attitudes with his father is significant. The father was and the son was to become vitally interested in politics and economics. Both men declared that an increasing concentration of wealth might destroy democratic government. The elder Dos Passos believed in reform, and he asserted his views with courage and independence, just as his son was to do. The father's thinking had an ethical basis. Despite some of his views on domestic politics and imperialism, members of the family remember the elder Dos Passos as a libertarian and an antimilitarist. ${ }^{74}$ Some of his ideas, such as that of an Anglo-American union, were as unorthodox as any that his son was to express. Both father and son complained of the tendency in America to over-value material goods, and both contrasted material surfeit with intellectual and artistic distinction.

Let us compare two quotations. The first is from the elder Dos Passos' pamphlet condemning the Republican Party in 1904. Dos Passos Sr. raised the problem of how important material prosperity is.

But the nation is deeply concerned with the question as to the influence which this prosperity has had upon the manhood and character of our people. Are we better for it? Have we made real ethical progress? Do we know ourselves better? Are we more elevated, refined and enlightened? How is our literature? How is histrionic art? Do we better understand the duties of citizenship? In the treatment of our neighbors -of our inferiors-are we just and fair? The picture of prosperity has two sides. The Republican party has only shown the nation the material, sensuous one. ${ }^{75}$

The other is from his son's impassioned essay "A Humble Protest," which appeared in the undergraduate literary magazine Harvard Monthly during his senior year. The essay is a condemnation of the industrial era.

Except for the single triumph of liberalism over superstition in all its forms, religious, political, moral, which was the French Revolution, can we honestly say that life is intenser, that art is greater, that thought is more profound in our age than in the reign of Elizabeth? . . . You cannot honestly affirm that opportunity for producing great art,- -and art is certainly one of the touchstones, if not the touchstone of a civili-

74 Cyril F. dos Passos stated in his letter: "Mr. dos Passos [sic] was always a "liberal," and would be called today a libertarian. . . . He was a great individualist, and believed that no restriction should be placed upon anyone's action, so long as he did not commit a breach of the peace."

John Dos Passos added an unexpected note: “It's hard for you to imagine how normal for an American an anti-militarist attitude was before 1917-My father bitterly opposed the Spanish-American war." Letter to author, January 1957.

75 Dos Passos Sr., Trend of the Republican Party, p. 77. 
zation,- - or even the opportunity for a general interest in the forms of beauty, is greater than it was three centuries and a half ago. Most thoughtful people will say it is less. . . . ${ }^{76}$

Like his father, Dos Passos attacked materialism; but he showed in his essay a concern with the economically depressed classes of society which was absent in the father's writings. Dos Passos also placed a much higher value on the French Revolution than did Dos Passos Sr. who seems to have steeped himself in the philosophy and values of eighteenth-century American Federalism.

If we are to discuss revolutions, we ought not to forget that eighteenthcentury Federalism did not disown them. Nor ought we to forget the elder Dos Passos' pamphlet on Cuba, for part of his reasoning there is based on Locke's defense of the English Revolution of 1688 and on the philosophical justification of the American Revolution. It may seem strange that we should stop to consider arguments that must have been on the tongues of many people during the Cuba crisis of the 1890s and with which everyone is more or less familiar. But it is important that Dos Passos was exposed to a philosophy that held rebellion to be a possibility and a right and that he very likely heard it vigorously proclaimed by a conservative gentleman who admired Burke, 77 abhorred radicalism and never dreamed of his son's applying revolutionary doctrine to the United States. What might happen, though, if the son should become convinced that personal liberty and personal security were being abolished by an oligarchy (the father used that word over and over again ${ }^{78}$ ) in the United States and should become despondent about the possibility of democratic redress? The novelist was to come to such convictions and despondency between 1917, when the United States entered World War I, and 1927, when Massachusetts executed the radicals Sacco and Vanzetti.

76 John Dos Passos, “A Humble Protest," Harvard Monthly, LXII (June 1916), 118. 77 Dos Passos Sr., Commercial Trusts, p. 121.

78 Dos Passos Sr., Commercial Mortmain, pp. 52, 84, 97. 